\title{
METODE PENETAPAN TITIK KERITIS, DAYA SIMPAN DAN KEMASAN PRODUK INSTAN FUNGSIONAL
}

\author{
Retti Ninsix, S.Tp., MP(1), Prof. Dr. Fauzan Azima, M.S ${ }^{(2)}$, \\ Dr. Ir. Novelina, MS ${ }^{(2)}$ dan Dr. Ir. Novizar Nazir, M.Si ${ }^{(2)}$ \\ ${ }^{(1)}$ Dosen Teknologi Pangan Faperta UNISI \\ ${ }^{(2)}$ Dosen Teknologi Pertanian Universitas Andalas Padang \\ retty.ninsix@yahoo.co.id
}

\begin{abstract}
Abstrak
Informasi umur simpan merupakan salah satu informasi yang wajib dicantumkan oleh produsen pada kemasan produk pangan, Kewajiban produsen untuk mencantumkan informasi umur simpan ini telah diatur oleh pemerintah dalam UU Pangan tahun 1996 serta PP Nomor 69 tahun 1999 tentang Label dan kadaluarsa (umur simpan) pada setiap kemasan produk pangan. Hal ini terkait dengan keamanan produk pangan tersebut dan untuk menghindari pengkonsumsian pada saat kondisi produk sudah tidak layak dikonsumsi. Untuk itu perlu ditelaah mengenai regulasi titik kritis, umur simpan dan kemasan, dalam upaya memperpanjang umur simpan produk pangan khususnya produk instan fungsional. Pengolahan untuk memperpanjang umur simpan produk pangan perlu mengantisipasi faktor-faktor yang dapat menimbulkan kerusakan mutu. Penentuan umur simpan juga perlu mempertimbangkan faktor teknis dan ekonomis berkaitan dengan upaya distribusi produk yang di dalamnya mencakup keputusan manajemen yang bertanggung jawab.
\end{abstract}

Kata Kunci : Titik Kritis, Umur Simpan, Kemasan, Instan

\section{PENDAHULUAN}

Masalah keamanan pangan masih merupakan masalah penting dalam bidang pangan dan perlu mendapat perhatian khusus dalam program pengawasan pangan. Penyakit dan kematian yang ditimbulkan melalui makanan sampai saat ini masih tinggi, walaupun prinsip -prinsip pengendalian untuk berbagai penyakit tersebut pada umumnya telah diketahui.

Pengawasan pangan yang mengandalkan pada uji produk akhir tidak dapat mengimbangi kemajuan yang pesat dalam industri pangan, dan tidak dapat menjamin keamanan makanan yang beredar di pasaran. Pendekatan tradisionil yang selama ini dilakukan dapat dianggap telah gagal untuk mengatasi masalah tersebut baik itu produk dalam bentuk instan fungsional.

Di masyarakat modern dewasa ini msyarakat membutuhkan produk pangan yang serba instan. Produk pangan yang dikehendaki oleh masyarakat moderen tidak hanya mempertimbangkan unsur pemenuhan sebagai makanan untuk menghilangkan rasa lapar. Kebutuhan manusia saat ini adalah produk pangan yang memiliki nilai kesehatan, praktis dan cepat dalam penyajian. Oleh karena itu, saat ini dibutuhkan suatu makanan yang mengandung antioksidan dan 
kandungan gizi lainnya yang diharapkan dapat melengkapi kebutuhan yang semakin meningkat dengan mempertimbangkan segi kesehatan dan kepraktisan seperti produk pangan Fungsional instan.

Pangan instan terdapat dalam bentuk kering atau konsentrat, mudah larut sehingga mudah untuk disajikan yaitu hanya dengan menambahkan air panas atau air dingin.

Membanjirnya produk makanan instan merupakan salah satu tuntutan di masa yang semakin maju, sehingga perkembangan serta prospek makanan instan masih sangatlah tinggi.

Produk instan diperoleh dengan melakukan instanisasi terlebih dahulu pada komponen penyusun produk instan. Instanisasi dapat dilakukan dengan bahan baku komponen penyusun yang telah berbentuk tepung menjadi adonan kental, dengan menggunakan cabinet dryer, hasil pengeringan akan dihancurkan dengan menggunakan pisau sehingga menghasilkan tepung berukuran 60 mesh. Bahan tepung yang diperoleh telah bersifat instan dan dikemas menjadi produk instan (Perdana, 2003).

Pengembangan produk pangan instan bertujuan memudahkan masyarakat saat mengkonsumsinya. Produk pangan instan sangat mudah disajikan dalam waktu yang relatif singkat. Membanjirnya produk makanan instan merupakan salah satu tuntutan di masa yang semakin maju ini, maka produk ini perlu dikomersil dengan melakukan pengemasan.

Pengolahan pangan pada industri komersial umumnya bertujuan memperpanjang masa simpan, mengubah atau meningkatkan karakteristik produk (warna, cita rasa, tekstur), mempermudah penanganan dan distribusi, memberikan lebih banyak pilihan dan ragam produk pangan di pasaran, meningkatkan nilai ekonomis bahan baku, serta mempertahankan atau meningkatkan mutu, terutama mutu gizi, daya cerna, dan ketersediaan gizi. Kriteria atau komponen mutu yang penting pada komoditas pangan adalah keamanan, kesehatan, flavor, tekstur, warna, umur simpan, kemudahan, kehalalan, dan harga. Untuk memperoleh keaanan dari produk instan tidak lepas dari rangkaian panjang dari pengujian dan analisa yang mencakup titik kritis, umur simpan, kemasan dan factor faktor lainnya. Permasalahan yang sering terjadi pada produk tepung-tepungan (instan) adalah sifatnya yang mudah menyerap air dari udara atau bersifat higroskopis. Adanya transfer uap air pada produk tersebut dapat menyebabkan perubahan yang tidak diinginkan dan memperpendek umur simpan.

\section{UMUR SIMPAN}

Umur simpan produk pangan merupakan suatu parameter ketahanan produk selama penyimpanan atau selang waktu antara produksi hingga konsumsi dimana produk masih berada dalam kondisi yang memuaskan konsumen berdasarkan karakteristik kenampakan, rasa, aroma, tekstur, dan nilai gizi (Institute of Food Science and Technology, 1974). Sementara, Floros dan Gnanasekharan (1993) menyatakan bahwa umur simpan adalah waktu yang dialami produk pangan dalam kondisi penyimpanan tertentu untuk dapat mencapai tingkatan degradasi mutu tertentu (dalam keadaan masih bisa dikonsumsi). Oleh karena itu umur simpan pada dasarnya dapat diduga dari perubahan mutu, namun demikian perlu dipilih parameter mutu yang tepat.

Pada saat baru diproduksi, mutu produk dianggap dalam keadaan $100 \%$, dan akan menurun sejalan dengan 
lamanya penyimpanan atau distribusi. Selama penyimpanan dan distribusi, produk pangan akan mengalami kehilangan bobot, nilai pangan, mutu, nilai uang, daya tumbuh, dan kepercayaan (Rahayu et al., 2003).

Penggunaan indikator mutu dalam penentuan umur simpan produk siap guna atau siap saji bergantung pada kondisi saat percobaan penentuan umur simpan tersebut dilakukan (Kusnandar, 2004). Floros dan Gnanasekharan (1993) menyatakan, factor - faktor yang menyebabkan terjadinya perubahan pada produk pangan tersebut dapat menjadi dasar dalam menentukan titik kritis umur simpan. Titik kritis ditentukan berdasarkan faktor utama yang sangat sensitif serta dapat menimbulkan terjadinya perubahan mutu produk selama distribusi, penyimpanan hingga siap dikonsumsi.

Umur simpan produk yang dianalisis secara obyekti dapat diperoleh dari analisis atau evaluasi sensori, analisis kimia dan fisik, serta pengamatan kandungan mikroba (Koswara, 2004). Penentuan umur simpan dengan menggunakan faktor organoleptik dapat menggunakan peubah sensori (warna, flavor, aroma, rasa, dan tekstur) terhadap sampel dengan skala $0-10$, yang mengindikasikan tingkat kesegaran suatu produk (Gelman et al., 1990).

Informasi umur simpan ini merupakan salah satu informasi yang wajib dicantumkan oleh produsen pada kemasan produk pangan. Pencantuman informasi umur simpan menjadi sangat penting karena terkait dengan keamanan produk pangan tersebut dan untuk menghindari pengkonsumsian pada saat kondisi produk sudah tidak layak dikonsumsi. Kewajiban produsen untuk mencantumkan informasi umur simpan ini telah diatur oleh pemerintah dalam
UU Pangan tahun 1996 serta PP Nomor 69 tahun 1999 tentang Label dan Iklan Pangan, dimana setiap industri pangan wajib mencantumkan tanggal kadaluarsa (umur simpan) pada setiap kemasan produk pangan disamping itu jenis dan bentuk kemasan juga sangat menentukan daya simpan dari pruduk. Untuk itu perlu diketahui titik keritis, umur simpan dan kemasan yang bisa meningkatkan daya simpan dari produk.

Floros (1993) melakukan penelitian umur simpan produk dapat diduga melalui 2 metode yaitu Extended Storages Studies (ESS) dan Accelarated Storage Studies (ASS).ESS sering disebut sebagai metode konvensional yaitu penentuan masa kadaluarsa dengan menyimpan suatu produk pada kondisi normal. Penentuan umur simpan produk dengan metode ASS atau sering disebut dengan ASLT dilakukan dengan menggunakan parameter kondisi lingkungan yang dapat mempercepat proses penurunan mutu (usable quality) produk pangan.

Labuza (1982), menyatakan penilaian umur simpan produk dapat dilakukan pada kondisi dipercepat (accelerated shelf life test) yang mampu memprediksi umur simpan produk. Metode ini dilakukan dengan mengkondisikan bahan pangan pada suhu dan kelembaban relatif tinggi.

Penentuan umur simpan metode Arrhenius termasuk kedalam metode akselerasi ini. Pada metode ASLT, suhu merupakan parameter kunci penentu kerusakan karena semakin meningkatnya suhu maka reaksi kerusakan akan semakin cepat.. Parameter utama yang digunakan adalah parameter yang dianggap paling mempengaruhi kemunduran mutu produk, yaitu kadar air, total mikroba dan kadarfree fatty acid (FFA). Kadar FFA dipilih sebagai parameter untuk menentukan masa 
kadaluarsa produk instan. Nilai Kadar FFA Produk kemudian diplotkan pada model Arrhenius sehingga diperoleh $\ln \mathrm{k}$ $=\ln \mathrm{k} 0-(\mathrm{E} / \mathrm{R})(1 / \mathrm{T})$. dari persamaan ini akan diperoleh nilai masing-masing energy aktivasinya (Ea). Selanjutnya penentuan umur simpan dihitung dengan kinetika reaksi berdasarkan orde reaksi.

Sudarmaji (2015), Pendugaan Umur Simpan dapat dilakukan dengan metode Arrhenius. Pemakaian model ini didasarkan pada waktu pelaksanaan yang singkat dan metode yang sederhana. Semakin lama penyimpanan dan semakin tinggi suhu penyimpanan menyebabkan peningkatan kadar air serta penurunan kadar volatile reducing substance, kadar antioksidan, kelarutan, dan kecerahan serbuk. Di dalam penentuan umur simpan perlu mempertimbangkan faktor teknis dan ekonomis dalam distribusi produk yang di dalamnya mencakup keputusan manajemen yang bertanggung jawab.

\section{KEMASAN}

Bucle et al. (1987) menyatakan, kemasan yang dapat digunakan sebagai wadah penyimpanan harus memenuhi beberapa persyaratan, yakni dapat mempertahankan mutu produk supaya tetap bersih serta mampu memberi perlindungan terhadap produk dari kotoran, pencemaran, dan kerusakan fisik, serta dapat menahan perpindahan gas dan uap air. Produk tanpa kemasan akan mengalami kerusakan mutu yang lebih cepat dibandingkan produk terkemas.

Salah satu jenis kemasan bahan pangan yaitu plastik. Faktor yang mempengaruhi konstanta permeabilitas pada kemasan plastik antara lain adalah jenis permeabilitas, ada tidaknya ikatan silang (cross linking), suhu, bahan tambahan elastis (plasticer), jenis polimer film, sifat dan besar molekul gas, serta kelarutan bahan.

Mustafidah., dkk (2015), menyatakan Permasalahan yang sering terjadi pada produk tepung-tepungan adalah sifatnya yang mudah menyerap air dari udara atau bersifat higroskopis. Adanya transfer uap air pada produk tersebut dapat menyebabkan perubahan yang tidak diinginkan dan memperpendek umur simpan. Salah satu cara untuk mengurangi masuknya uap air ke dalam produk yaitu kemasan yang memiliki daya tembus atau permeabilitas uap air yang rendah untuk menghambat penurunan mutu produk. Kemasan yang sering digunakan untuk produk tepungtepungan adalah LDPE dan PP. Permeabilitas polietilen densitas rendah (LDPE) terhadap uap air adalah sebesar $0.5 \mathrm{~g} / \mathrm{m} 2 \mathrm{hr} . \mathrm{mmHg}$ dan permeabilitas polipropilen (PP) terhadap air adalah sebesar $0.185 \mathrm{~g} / \mathrm{m} 2 \mathrm{hr} . \mathrm{mmHg}$.Metode yang dapat digunakan untuk mengetahui perubahan transfer uap air selama penyimpanan adalah pendekatan kadar air kritis. Metode ini merupakan penentuan umur simpan berdasarkan akselerasi RH yang ditentukan dari suatu kurva hubungan kadar air dengan aktivitas air (aw). Metode ini telah diterapkan pada bubur jagung instan dan tepung fermentasi dari sorgum coklat.

Rosalina,Y dan Silvia, E. (2015), menyatakan bahwa Suhu penyimpanan $35^{\circ} \mathrm{C}$ memiliki perubahan kadar air dan total mikroba terendah pada penyimpanan hari ke - 30 yaitu $4 \%$ dan 10 x 104 Cfu dari produk dalam bentuk tepung.

Pujiastuti, W., dkk (2013) melakukan penelitian tentang pengaruh Laju Transmisi Uap Air (WVTR) dari biopolimer blend Polibutilen Suksinat (PBS) dan Linear Low Density Polyethylene (LLDPE) terhadap umur simpan sup krim instan rasi telah 
dilakukan pada berbagai komposisi campuran PBS/LLDPE. Persentase komposisi campuran PBS/LLDPE yang digunakan untuk mengemas sup krim instan rasi berturut-turut adalah 30/70\%, $50 / 50 \%$, dan $70 / 30 \%$, dengan nilai WVTR berturut-turut adalah 9,06 $\mathrm{g} / \mathrm{m} 2$ hari; $16,92 \mathrm{~g} / \mathrm{m} 2$ hari dan 25,08 g/m2 hari. Dengan menggunakan metode kadar air kritis diperoleh umur simpan terpanjang dari sup krim instan rasi adalah 13 hari yang dikemas dalam campuran PBS/LLDPE 30/70\%.

Sudibyo, A dan Tiurlan F. Hutajulu (2013), Hingga saat ini bahan yang digunakan untuk kemasan pangan merupakan bahan yang tidak mudah diurai dan menimbulkan permasalahan terhadap lingkungan. Sifat permeabilitas dan mekanis serta hambatannya yang rendah terhadap uap dan gas yang dimiliki oleh matriks polimer, telah mendorong ketertarikan dalam strategi baru untuk mengembangkan perbaikan sifat - sifat tersebut. Penelitian dan pengembangan bahan polimer dengan cara memadukan bahan pengisi yang tepat, melalui interaksi matriks bahan pangan strategi formula baru.

Menurut Tung dkk (2001), umur simpan merupakan konsep yang kompleks yang bergantung pada sifatsifat dasar dari produk makanan, teknologi pengawetan yang digunakan, dan kondisi lingkungan produk pangan tersebut digunakan. Pengemasan memegang peranan penting dalam memelihara kualitas dan umur simpan suatu produk pangan, dimana menjadi bagian utuh dalam system pengawetan pangan. Umur simpan atau masa kadaluarsa merupakan suatu parameter ketahanan produk selama penyimpanan. Secara umum dapat dikatakan bahwa kadar air dan aktivitas air $\left(a_{\mathrm{w}}\right)$ sangat berpengaruh dalam menentukan umur simpan dari produk pangan, karena faktor-faktor ini akan mempengaruhi sifat-sifat fisik (kekerasan dan kekeringan) dan sifat-sifat fisiko kimia, perubahan-perubahan kimia (pencoklatan non enzimatis), kerusakan mikrobiologis dan perubahan enzimatis terutama pangan yang tidak diolah. Oleh karena itu perlu dikembangkan suatu sistem jaminan keamanan pangan yang disebut Analisis Bahaya dan Pengendalian Titik Kritis (Hazard Analysis Critical Control Point /HACCP) yang merupakan suatu tindakan preventif yang efektif untuk menjamin keamanan pangan. Sistem ini mencoba untuk mengidentifikasi berbagai bahaya yang berhubungan dengan suatu keadaan pada saat pembuatan, pengolahan atau penyiapan makanan, menilai risiko.

\section{MEMPERPANJANG UMUR SIPAN}

Mutu dari produk pangan akan mengalami perubahan (penurunan) selama proses penyimpanan. Umur simpan produk pangan dapat diperpanjang dengan diketahui factor faktor yang mempengaruhi masa simpan dari produk. Upaya memperpanjang masa simpan dapat dilakukan dengan beberapa cara, yaitu meningkatkan nilai mutu dan memperlambat laju penurunan mutu.

Peningkatan nilai mutu awal produk dapat dilakukan dengan memilih dan menggunakan bahan baku yang bermutu baik. Dengan menaikkan mutu awal akan dapat memperpanjang masa kedaluwarsa. Dengan cara meningkatkan mutu awal produk pangan, yaitu dengan menggeser kualitas (mutu) menjadi lebih meningkat pada akhirnya akan dapat menggeser masa kedaluwarsa lebih lama.

Perlambatan laju penurunan mutu produk juga dapat dilakukan dengan memperbaiki kemasan, faktor penyimpanan, faktor penanganan 
distribusi atau factor penanganan lainnya. Dengan penambahan alternatif tersebut, pada akhirnya dapat meningkatkan masa kedaluwarsa produk pangan. Dengan cara memperlambat laju penurunan mutu produk melalui alternative penanganan produk pangan, pada akhirnya dapat menggeser masa kedaluwarsa lebih lama.

Pengolahan produk pangan, selain dapat memperpanjang umur simpan juga mempengaruhi komponen yang terkandung dalam produk pangan tersebut. Beberapa proses penanganan produk pangan yang dapat menyebabkan terjadinya perubahan mutu adalah perlakuan panas tinggi, pembekuan, pengemasan, pencampuran, serta pemompaan. Pengeringan dapat memperpanjang umur simpan. Namun, pada proses pengeringan perlu diperhatikan agar air yang keluar dari bahan tidak merusak struktur jaringan, sehingga mutu bahan pangan dapat dipertahankan (Komari 1986).

Perlakuan panas seperti blanching, pasteurisasi, dan pemanasan dengan alat retort pada buah-buahan dan sayuran dapat menurunkan tingkat kesegaran dan menyebabkan produk menjadi lebih lunak (Huang dan Bourne 1983; Togeby et al. 1986). Pelunakan produk terjadi karena adanya degradasi dan pelarutan senyawa pektin pada dinding sel dan bagian tengah lamella (Waldron et al. 1997). Oleh karena itu, pengolahan produk pangan untuk memperpanjang umur simpan perlu memperhatikan faktor lain yang dapat menimbulkan kerusakan mutu.

\section{KESIMPULAN DAN SARAN}

Pencantuman tanggal kedaluwarsa produk pangan telah diatur dalam UU Pangan No. 7 tahun 1996 dan PP No. 69 tahun 1999. Penentuan umur simpan perlu memperhatikan parameter umur simpan, terutama titik kritis. Terdapat lima pendekatan yang dapat digunakan dalam penentuan umur simpan produk pangan sebelum dipasarkan, yaitu literature value, distribution turn over, distribution abuse test, complain konsumen, dan ASLT. Penentuan umur simpan dapat dilakukan dengan cara konvensional (ESS) atau dengan percepatan dengan menggunakan metode ASS. Faktor kemasan perlu diperhatikan dalam penentuan umur simpan, terutama permeabilitas kemasan.

Untuk memperpanjang umur simpan produk pangan dapat dilakukan dengan peningkatan mutu awal atau dengan perlakuan selama proses penyimpanan. Pengolahan untuk memperpanjang umur simpan produk pangan perlu pula mengantisipasi faktor lain yang dapat menimbulkan kerusakan mutu. Penentuan umur simpan sebaiknya mempertimbangkan faktor teknis dan ekonomis dalam upaya distribusi produk yang di dalamnya mencakup keputusan manajemen yang bertanggung jawab.

\section{DAFTAR PUSTAKA}

Ademiluyi, A, O., Oboh, G. 2011. Soybean phenolic-rich extracts inhibit key-enzymes linked to type 2 diabetes $\alpha$-amylase and $\alpha$ glucosidase) and hypertension (angiotensin I converting enzyme) in vitro. Experimental and Toxicologic Pathology 65 (2013) 305- 309.

Bucle, K.A., R.A. Edwards, G.H. Fleet, dan M. Woofon. 1987. Ilmu Pangan. UI Press, Jakarta.

Floros, J.D. and V. Gnanasekharan. 1993. Shelf life Prediction of Packaged Foods: Chemichal, Biological, Physical, and Nutritional aspects. G. Chlaralambous (Ed.). Elsevier Publ.,London. 
Gelman, A., R. Pasteur, and M. Rave. 1990. Quality Change and Storage life of Cammon carp (Cyprinus carpio) at Various Storage Temperatures. J. Sci. Food Agric. 52: $231-241$

Huang, Y.T. and M.C. Bourne. 1983. Kinetics of Thermal Softening of Vegetable. J. Texture Study 14(1): $1-9$.

Komari. 1986. Mempelajari Proses Pengeringan Seripih. Media Teknologi Pangan 6(4): 2.

Labuza, T. P. 1982. Open Shelf Life Dating of Foods. Food Science and 1

Mustafidah, dkk. 2015. Umur Simpan Minuman Serbuk Berserat dari Tepung Porang. Jurusan Teknologi Hasil Pertanian, FTP Universitas Brawijaya. Malang. Jurnal Pangan dan Agroindustri Vol. 3 No 2 p. April 2015. Halaman 650-660

Sudibyo, A dan Tiurlan F.Hutajulu. 2013. Potensi Penerapan Polimer Minokomposit dalam Kemasan Pangan.Balai Besar Industri Agro (BBIA) Kementerian Perindustrian. Fakultas Teknologi Pertanian-Universitas Padjadjaran Bandung. Terakreditasi Nomor : 526/AU1/P2MI-LIPI/04/2013.

Vol. 35 No.1 April 2013 ISSN 2088 - 026X. Halaman 6-19

Rosalina,Y dan Silvia, E. 2015. Study of Quality Changis During Storage and Shelf Life Prediction of Beledang Fish Chips In Rigid Pplypropylene Packaging . JTIP
Indonesia. - Vol7. , No. 1, 2015. Halaman 1-6.

Pudjiastuti,W., dkk. 2013. Polibutiten Suksinat (PBS) dan Linear Low Density Polyethylene (LLDPE) terhadap Umur Simpan Sup Krim Instan Rasi. Fakultas Teknologi Pertanian-Universitas Padjadjaran Bandung. Jurnal Kimia dan Kemasan. Terakreditasi Nomor : 526/AU1/P2MI-LIPI/04/2013.

Vol. 35 No.1 April 2013 ISSN 2088 - 026X. Halaman 1-5

Rahayu, W.P., H. Nababan, S. Budijanto, dan D.Syah. 2003. Pengemasan, Penyimpanan dan Pelabelan. Badan Pengawasan Obat dan Makanan, Jakarta.

Waldron, K.W., A.C. Simth, A.J. Palr, and M.L.Parker. 1997. New Approaches to Understanding and Controlling cell Separation in relation to fruit and vegetable texture. Trend Food Sci. Technol. 8: 213-221.

Togeby, M., N. Hansen, E. Mosekilde, and K.P. Poulsen. 1986. Modelling Energy Consumption, loss of Firmness and Enzyme in avtivity in an Industrial Blanching proses. J. Food Eng. 5: 251-267.

Waldron, K.W., A.C. Simth, A.J. Palr, and M.L. Parker. 1997. New Approaches to Understanding and Controlling Cell ISeparation in Relation to Fruit and Vegetable Texture. Trend Food Sci. Technol. 8: 213-221. 